This is the post-print version of a published work. Please, cite as:

CATALAN, Jordi and RAMON-MUÑOZ, Ramon (2013): "Marshall in Iberia. Industrial Districts and Leading Firms in the Creation of Competitive Advantage in Fashion Products",

Enterprise \& Society, vol. 14, no. 2, pp. 327-359

DOI: http://dx.doi.org/10.1093/es/kht019

\title{
Marshall in Iberia. Industrial Districts and Leading Firms in the Creation of Competitive Advantage in Fashion Products ${ }^{*}$
}

\author{
Jordi Catalan \\ Ramon Ramon-Muñoz
}

\begin{abstract}
Firms dealing with "Made in Spain" fashion products (e.g., textiles, apparel, and footwear) have increased their presence in the world market over the last two decades. This paper focuses on the origins of this process. After constructing a new database of export districts, it first investigates the sources of the international competitiveness of these districts. Second, it explores whether industrial districts boosted the internationalization of Spanish fashion firms. The paper concludes that most of today's outstanding Spanish firms in fashion-related international markets emerged from 1980s' districts, which could have benefited from classical Marshallian externalities, while also taking advantage of the organizational capabilities of leading firms.
\end{abstract}

\footnotetext{
- Jordi Catalan Vidal, Departament d'Història i Institucions Econòmiques, Centre d'Estudis Antoni de Capmany d'Economia i Història Econòmica (CEAC), Facultat d'Economia i Empresa, Universitat de Barcelona, Av. Diagonal, 690, 08034 Barcelona. E-mail: jordi.catalan@ub.edu.

Ramon Ramon-Muñoz, Departament d'Història i Institucions Econòmiques, Centre d'Estudis Antoni de Capmany d'Economia i Història Econòmica (CEAC), Facultat d'Economia i Empresa, Universitat de Barcelona, Av. Diagonal, 690, 08034 Barcelona. E-mail: ramon@ub.edu

We would like to thank the editor and three anonymous referees for their helpful suggestions. Earlier versions of this paper were presented at the 13th Meeting of the European Business History Association and the 55th Meeting of the Business History Conference (Milan, 2009), the 15th World Economic History Congress (Utrecht, 2009), the Workshop "Los distritos industriales y los clusters ante la crisis económica internacional" (Bellaterra, 2010), and the 35th Meeting on Regional Studies-AECR (Badajoz, 2010). We thank the participants in these meetings for their comments, particularly Franco Amatori and John F. Wilson as well as Andrea Colli, Rafael Boix, Manuel Expósito-Langa, Francesc Xavier Molina, Francisco Puig Vicent Soler, and Josep Lluis Ybarra. We are also grateful to Guillermo Gil-Mugarza for research assistance and to Eva Angrill for helping us with maps. This research has benefited from the financial support of the Spanish Ministry of Science and Innovation through the project HAR2009-07571 and the Spanish Ministry of Economy and Competitiveness through the project HAR2012-33298. The authors also acknowledge the support from the Network in Economics and Public Policies (XREPP), launched by the Generalitat de Catalunya, and the Centre d'Estudis Antoni de Capmany d'Economia $\mathrm{i}$ Història Econòmica (Universitat de Barcelona). The usual disclaimer applies.
} 


\section{Introduction}

Today, Spain has the world's largest fast-fashion retailing firm: the group Inditex, with its main brand Zara. Although the company's founder was already in business in 1963, the firm only opened its first store abroad in 1988. Since then, its growing presence in the international market has gone hand in hand with innovations such as the adoption of just-in-time techniques to fashion production and retailing. ${ }^{1}$ Other "made in Spain" fashion firms have increasingly been penetrating foreign markets over the last two decades. The growing acceptance of their products abroad has paralleled the internationalization of the Spanish fashion-related industry. What are the origins and roots of this process? What factors did contribute to the international takeoff of Spanish fast-fashion firms? Answers to these questions may be of interest not only to those interested in explaining the formation of the competitive advantage of industries and firms. they may also help to provide new evidence to the business history of fashion, a field that is attracting a growing interest among scholars. ${ }^{2}$ In particular, this paper discusses to what extent external economies boosted the success of Spanish fashion firms abroad by exploring Spanish export districts for textiles, clothing, and shoemaking during the 1980s, just before the most important "made in Spain" fashion firms began to internationalize. ${ }^{3}$

The literature on the so-called "district effect" suggests that geo- graphical concentration may have boosted exports in textile, clothing, and shoemaking. ${ }^{4}$ A crucial point made in this literature is that firms in industrial districts enjoy certain advantages over the rest due to external economies of scale through spatial concentration. ${ }^{5}$ In this regard, a number of empirical studies have concluded that either productivity or the level of innovation tends to be higher among firms located in industrial districts than in the rest of the industry. Furthermore, other authors have argued that firms' cooperation in industrial districts may strengthen their international competitiveness. ${ }^{6}$

The paper is organized as follows. First, the main literature on Marshallian external economies as a source of competitiveness is surveyed. Second, a new method to identify industrial districts according to their competitive advantage is proposed, and it is then applied to a Spanish textile, clothing, and shoemaking firms' database for the 1980s.

\footnotetext{
${ }^{1}$ Alonso, "Vistiendo a 3 continentes"; Alonso, "Competitividad internacional”; O’Shea, Así es Amancio Ortega; Tokatli, "Global Sourcing."

2 See, among others, the articles included in the book Producing Fashion, edited by Blaszczyk, those published in the special issue of Business History coordinated by Polese and Blaszczyk, "Fashion Forward"; and for the particular case of the international success of the Italian fashion industry in the second half of the twentieth century, see Merlo and Polese, "Turning Fashion into Business"; and Merlo, "Italian Fashion Business."

${ }^{3}$ Boix and Galletto provided data for 2001 indicating that one-third of the existing Spanish industrial districts were specialized in textile and shoemaking activities. See Boix and Galletto, "Sistemas locales," 171.

${ }^{4}$ In Dei Ottati's words, the "district effect" can be defined as the "collection of competitive advantages derived from a strongly related set of economies, which are external to the single firms, but internal to the district." Dei Ottati, "El 'efecto distrito"," 74-75. The translation is ours.

${ }^{5}$ See, for example, Boix and Trullén, "Industrial Districts," for a review of this literature.

6 See Bagella, Becchetti, and Sacchi, "The Positive Link"; Becchetti and Rossi, "UE and Non UE"; Bronzini, "Sistemi produttivi locali"; Bugamelli and Infante, "I costi irrecuperabili"; Costa-Campi and Viladecans-Marsal, "The District Effect"; or Gola and Mori, "Concentrazione spaziale." Additional evidence on the district effect with respect to firms' productivity has been provided among others by Signorini, "The Price of Prato"; Soler, "Verificación de las hipótesis"; Molina, "European industrial districts"; Pla-Barber and Puig, "Is the Influence"; and Llonch, "Trademarks, product differentiation and competitiveness."
} 
Third, the resulting districts are classified by using export concentration indicators. Fourth, the role these districts played in the recent internationalization of the main "Made in Spain" fashion firms is evaluated. Finally, the main conclusions of the paper are summarized.

\section{Neo-Marshallian Districts versus Hub-Firm Clusters in the Formation of Competitive Advantage: A Survey}

Firms in similar or related industries can benefit from external economies of scale through spatial concentration, and this concentration can also become a source of competitive advantage in industry. The English economist Alfred Marshall established the basis for these arguments. According to Marshall, a geographically localized industry could benefit from several types of external economies. The first has to do with non-codified knowledge, since "if one man starts a new idea, it is taken up by others and combined with suggestions of their own; and thus it becomes the source of further new ideas." Another type of external economy is related to the emergence of subsidiary industries, which can be set up because in a district "there is a large aggregate production of the same kind, even though no individual capital employed in the trade be very large." Marshall argued that "a localized industry gains a great advantage from the fact that it offers a constant market for skill. Employers are apt to resort to any place where they are likely to find a good choice of workers with the special skill which they require,"9 This triad of advantages, namely knowledge spillovers, subsidiary industries, and specialized labor, can be considered the economic foundations of the pure or classical Marshallian industrial district.

For many years, however, Marshall's arguments rarely featured among economic debates, and it was only in the 1970s and early 1980s that a number of scholars analyzing the Italian economy recovered and expanded upon his ideas on industrial organization. Thus, authors such as Becattini, Brusco, Bagnasco, and Piore and Sabel added to the Marshallian triad two new types of advantages for those industries that were geographically concentrated: the small size of firms and the existence of a dense network of local institutions. ${ }^{10}$ According to these authors, the intense competition derived from a high concentration of small firms tended to give flexibility to the district, while robust local institutions and culture could provide other long-term benefits. One of these was the prevalence of cooperative attitudes among social actors. Thanks to both a firm's flexibility and the existence of strong institutions and culture at local level, the Italian industry would have improved its competitiveness in the world market during the golden age and the stagflation crisis. ${ }^{11}$ Districts enjoying the triad of advantages

\footnotetext{
${ }^{7}$ Marshall, Principles of Economics, 271.

${ }^{8}$ Ibid.

${ }^{9}$ Ibid.

${ }^{10}$ Becattini, Lo sviluppo economico; Becattini, "Dal settore"; Becattini, Il bruco; Brusco, "Economie di scala"; Brusco, "The Emilian Model"; Bagnasco, Tre Italie; and Piore and Sabel, The Second Industrial Divide.

${ }^{11}$ Clear cases of successful performance were found all over the Third Italy: textile districts in Prato (Tuscany) or Carpi (Emilia-Romagna), apparel districts in Noventa Vicentina (Veneto) or Roseto (Abruzzi), footwear districts in San Giovanni Ilarione (Veneto) or Fermo (Marche), and leather districts in Santa Croce Sull'Arno (Tuscany) or Tolentino (Marche). See Becattini, Lo sviluppo economico; Becattini, Mercato e forze locali; Becattini, Il bruco; Brusco, "Economie di scala"; Bagnasco, Tre Italie; Sforzi, "L'identificazione spaziale"; Dei Ottati, "Trust, Interlinking Transactions and Credit"; Dei Ottati,
} 
enumerated by Marshall and having the characteristics detailed by Italian scholars could thus be referred to as neo-Marshallian districts. ${ }^{12}$

Michael E. Porter reassessed the importance of agglomeration economies by arguing they were critical to firms' competitiveness. ${ }^{13}$ He analyzed the factors that lie behind the competitive advantage of nations, illustrating them in his famous Porter's diamond. Porter argued that there were three main reasons why geographical agglomeration boosted firms' international competitiveness. First, it allowed companies to operate more productively. ${ }^{14}$ Second, it enhanced innovation due to both rivalry and proximity among firms. And third, it favored the emergence of new firms, in part because barriers to entry are lower than elsewhere since "needed assets, skills, inputs and staff are often readily available." 15 Interestingly, when defining the spatial concentration of economic activity, Porter did not use the concept of industrial district but that of cluster, which he defined as a concentration of interconnected firms and institutions in a specific territory and industry. ${ }^{16} \mathrm{He}$ also argued that neither the size of firms nor their sector specialization were crucial issues in the identification of clusters. Therefore, his conception of cluster did not require the prevalence of manufacturing activities or the dominance of small-medium firms. In this respect, it is worth noting that although Porter argued that agglomeration economies could boost competitive advantage, he also stressed the role of firms' strategies as a source of the success of nations or industries in world markets.

Historiography has increasingly stressed that geographical agglomeration might consist of a number of key large firms that dominate the regional economy. Economic geographers such as Ann Markusen suggested that the industrial districts of the Italianate type were more the exception than the rule in the United States. ${ }^{17}$ In fact, together with the Italianate district she identified additional types of industrial districts, such as hub-and-spoke districts, satellite platform districts, and state-anchored districts, with the former type being among the most prominent in the United States. ${ }^{18}$ According to Markusen, districts with hub-and-spoke firms tended to be a more representative form of localized industry in mature industrial economies. This type of industrial district shared with its neo-Marshallian counterparts the presence of a dense network of interrelated firms, but the cluster core belonged to one or several large and vertically integrated firms surrounded by suppliers that acted as coordinators of the system. In fact, hub-and-spoke districts were characterized by substantial intradistrict trade among

\footnotetext{
"Exit, Voice." In the canonical case of Prato, for example, Dei Ottati showed that the real value of exports quadrupled between 1963 and 1981.

12 Zeitlin, "Industrial Districts."

${ }^{13}$ Porter, The Competitive Advantage.

14 The reasons for this were that by means of agglomeration: (1) the supply of specific inputs increased, for example, workers with industry-specific training and intermediate inputs; (2) information and ideas flowed more easily due to proximity; (3) firms could take advantage of a set of related and supporting industries, activities, and services; (4) they could also more easily access institutions, including public goods such as education; and (5) competition among firms emerged, which motivated them to improve.

${ }^{15}$ Porter, "Clusters and the New Economics," 84.

16 Porter, "Clusters and the New Economics"; and Porter and Ketels, "Clusters and Industrial Districts."

${ }^{17}$ Markusen, "Sticky Places."

${ }^{18}$ Ann Markusen's typology seems particularly useful to discuss the sources of competitive advantage of industries and nations. We find many points in common between Zeitlin's neo-Marshallian notion and Markusen's Italianate districts.
} 
dominant firms and suppliers, as well as by longterm contracts and commitments between the former and the latter. ${ }^{19}$

The role of leading firms and internal economies may be important in many other respects. From a Schumpeterian perspective, evolutionary economists pointed out the key innovative role performed by large firms. ${ }^{20}$ In addition, Nelson and Winter stressed the cumulative learning-based view of organizational competence by emphasizing the development of capabilities, considering business firms as organizations where effective routines emerge and evolve. ${ }^{21}$ Although more effective ways of doing things are created and spread, routines are like genes; inheritance tends to be crucial as a source of success in industrial competition. Recent research on the development of the most impressive industrial clusters in the United States suggests that leading firms in the industry tended to generate similarly competitive spinoffs with good chances of surviving in the competitive arena. Therefore, organizational reproduction and heredity are said to be the primary forces underlying the clustering of industry. ${ }^{22}$ From the business history perspective, it has been argued that firms' strategy, internal economies, and organizational capabilities are what mostly lie behind the formation of competitive advantage in industries or territories. Alfred D. Chandler was perhaps the most prominent scholar to take this stance. ${ }^{23}$ His work has been at the heart of the controversies between the leading business historians in America, Europe, and Asia during recent decades. ${ }^{24}$ It has also had an enormous influence in areas such as strategy, organization, and management of firms, particularly among evolutionary economists. ${ }^{25}$ Chandler argued in one of his last works that a common feature of the three technological revolutions was that they all took place while clustered into very specific areas. ${ }^{26}$ Moreover, he always stressed that success in foreign markets required the prior emergence of firms that were large enough, and which had developed organizational capabilities, a concern shared by evolutionary economists. ${ }^{27}$ More precisely, he suggested that organizational capabilities were based on three types of knowledge or

\footnotetext{
${ }^{19}$ Although these are key features in hub-and-spoke districts, Markusen also identifies a number of other factors that characterize this sort of districts. For example, labor market is less flexible and workers' loyalties are to core firms first relative to the Italianate model. Similarly, trade associations tend to be few and weak, while hub-firms try to impinge upon local governments to ensure that politicians ensure their interests. In any case, if in Markusen's typology hub-and-spoke districts differed from the Italianate ones, they also clearly differed from satellite platform districts, another prominent type of district in the United States that was characterized by the absolute dominium of multinational subsidiaries. Hub-andspoke districts were also different from the state-anchored industrial districts, which were dominated by one or several large government institutions, including military bases, state or national capitals, or large public universities. Markusen, "Sticky Places."

${ }^{20}$ Freeman, The Economics of Industrial Innovation; Freeman, "The 'Nations System of Innovation'."

${ }^{21}$ Nelson and Winter, An Evolutionary Theory, 95, 37. Cimoli, Dosi, and Stiglitz, "The Political Economy," 2. For further discussion on the concepts of routines and organizational capabilities, see also Dosi, Nelson, and Winter, "The Nature and Dynamics"; and for the term dynamic capabilities, see Teece, Pisano, and Shuen, "Dynamic Capabilities."

${ }^{22}$ Klepper and Simons, "Dominance by Birthright"; Klepper, "The Origin and Growth of Industry Clusters."

${ }^{23}$ Chandler, Scale and Scope; Chandler, "Organizational Capabilities."

${ }^{24}$ Tolliday et al., "Scale and Scope"; Scranton, Endless Novelty; Chandler, Amatori, and Hikino, Big Business; Wilson and Popp, "Conclusion"; Popp and Wilson, "The Emergence of Industrial Districts"; Scranton, "Beyond Chandler"; Amatori, "Business History"; Amatori, "Business History as History"; Chandler, Shaping the Industrial Century.

${ }^{25}$ See, for example, the essays and interviews published in the 2010 special issue of Industrial and Corporate Change, presented by Lazonick and Teece. Lazonick and Teece, "Introduction."

${ }^{26}$ Chandler, Shaping the Industrial Century.

${ }^{27}$ Nelson and Winter, An Evolutionary Theory; Nelson and Winter, "Evolutionary Theorizing."
} 
capabilities (technical, functional, and managerial), which may contribute to create powerful barriers to entry. ${ }^{28}$ Chandler concluded that firms' organizational capabilities proved to be crucial for the conquest of foreign markets. He also stressed another important point. Together with developing organizational capabilities, in some industries large firms were able to become the node of a network of firms, in the sense that suppliers and subcontractors organized around a large industrial enterprise. ${ }^{29}$

Even in Italy, authors who have revisited the history of the industrial district are critical of the neo-Marshallian canonical type. For example, Lazerson and Lorenzoni challenged the dominant view that industrial districts always develop in opposition to large firms. They presented evidence on fashion districts, such as the Castel Gofredo women's stocking cluster in Lombardy, which shows an astonishing market concentration in panty-hose production. ${ }^{30}$ On the other hand, Rinaldi argued that typical small-firm districts where leading firms did not emerge, such as the knitwear district of Carpi (in Emilia-Romagna in the Third Italy), experienced a sharp decline in the late 1980s. In fact, the Italian fashion industry has been increasingly dominated by large firms, such as Benetton, or pocket multinationals, such as Geox. ${ }^{31}$ Recent work on industrial districts also tends to confirm the relative decline of the canonical type and a relatively better performance of leading firms in the world market. ${ }^{32}$

\section{Identifying Marshallian Exporting Districts}

At this point it is necessary to ask whether the Spanish export districts for textiles, apparel, and footwear fell, during the 1980s, into the category of neo-Marshallian districts, as opposed to being hierarchical districts coordinated by hub-firms. Prior to answering this question, we must first identify the exporting industrial districts for textiles, footwear, and shoemaking. Although there are several ways of identifying industrial districts, the most widely accepted approach is the so-called Sforzi-ISTAT methodology, which was first applied in Italy by Fabio Sforzi and the Istituto Centrale di Statistica (ISTAT). This methodology was both revised and improved in 2005.

[Table 1 about here]

By using the Sforzi-ISTAT methodology, Boix and Galletto developed a map of industrial districts in Spain for 2001, which has since been compared to both the Italian and the British ones. ${ }^{33}$ They found that Spain had 205 local labor markets with characteristics of neo- Marshallian industrial districts. These districts accounted for 20 percent of total jobs and 35 percent of total manufacturing employment in Spain.

\footnotetext{
28 According to Chandler, organizational capabilities "were created during the knowledge-acquiring processes that are always involved in commercializing a new product for national and international markets. These learned capabilities resulted from solving problems of scaling up the processes of production, from acquiring knowledge of customers' needs and altering product and process to services needs, coming to know the availabilities of supplies and the reliability of suppliers, and in becoming knowledgeable in the ways of recruiting and training workers and managers." Chandler, "Organizational Capabilities," 84. See also Chandler, Shaping the Industrial Century, 6-9.

${ }^{29}$ Chandler and Hikino, "The Large Industrial Enterprise," 36; Amatori and Colli, Business History, 145; Catalan, Miranda, and Ramon-Muñoz, eds., Distritos industriales; Le Bot and Perrin, eds., Les chemis de l'industrialisation.

${ }^{30}$ Lazerson and Lorenzoni, "The Firms," 242.

${ }^{31}$ Rinaldi, "The Italian Model Revisited"; Crestanello and Tattara, "A Global

Network"; Colli, Il Quarto Capitalismo.

32 Ramazzotti, "Industrial District."

${ }^{33}$ Boix, "Los distritos industriales"; Boix and Galletto, "Sistemas locales"; Boix and Galletto, "The New Map"; and Boix and Galletto, "Marshallian Industrial Districts."
} 
According to Boix and Galletto's data, textiles and apparel products, as well as leather and footwear, were among the industries with the largest number of neo-Marshallian industrial districts, ranking first and third respectively in the Spanish list of industrial districts. Interestingly, these two industries also topped the Spanish ranking regarding the share of total employment in the sector that was accounted for by industrial districts (see table 1).

Although very useful in comparative analyses, the Sforzi-ISTAT methodology is not exempt from problems, and most authors who have used it explicitly recognize this. For the purposes of this paper, three main limitations need to be pointed out. The first is that the Sforzi-ISTAT methodology does not offer a precise account of the existing industrial districts. This is because it does not take into account multi-specialized districts, since it only considers the main industry of the local labor market. Therefore, many industries are excluded during the identification process, even though they do constitute an industrial district.

The second limitation of the Sforzi-ISTAT methodology concerns the definition of industrial district itself. According to the methodology, industrial districts are associated with small-medium firms, and this leads to the exclusion of geographically concentrated industries that are characterized by a notable presence of large firms. As Boix and Galletto point out, in the Sforzi-ISTAT methodology "the taxonomy is rigorously dichotomous a local system is a district or it is not a district," which suggests that the map of Marshallian industrial districts should be complemented by an analysis of manufacturing systems of large firms. ${ }^{34}$ In addition, a certain degree of arbitrariness is observed in defining small, medium, and large firms.

The third limitation of the Sforzi-ISTAT methodology has to do with the fact that it relies on employment data. This methodology is based on the identification of local labor markets, which means that employment is the variable taken into account when identifying industrial districts. The extreme dependence on employment data may represent a serious shortcoming when the aim of research is to identify export districts, or when a study seeks to determine the competitive advantage of districts.

Of course, this is precisely what the present paper aims to do for the Spanish textile, apparel, and footwear industries during the 1980s. Therefore, a new database was created for 1987, one year after Spain had become member of the EEC, through the use of secondary sources, including business magazines and other complementary publications. ${ }^{35}$ At the present stage of our research, this database consists of 470 exporting firms distributed around 190 municipalities. ${ }^{36}$ Although the new database does not include all export firms, it covers almost 60 percent of total Spanish exports in textile, clothing, leather, and shoemaking products. ${ }^{37}$

\footnotetext{
${ }^{34}$ Boix and Galletto, "The New Map," 7. See also Trullén, "Distritos industriales marshallianos."

35 The main source has been Fomento de la Producción, 1988, which provides information for 1987 on exports at firm level valued at current pesetas. This source includes data for companies exporting above 20 million pesetas (about 162,000 1987 US dollars). It also informs on both the activity and the location of the listed firms. As our purpose is to identify exporting industrial districts, we have complemented this information with data on the location of the firm's plant by using a large variety of secondary sources.

36 The main descriptive statistics of this new database can be summarized as follows: mean exports per firm, 4.40 million 1987 dollars; median exports per firm, 2.18 million 1987 dollars; minimum export per firm, 0.16 million 1987 dollars; maximum export per firm, 76.97 million 1987 dollars; standard deviation, 7.18; first quartile, 0.89; third quartile 5.15.

${ }^{37}$ Instituto Nacional de Estadística, "Anuario estadístico," 379-80.
} 
A first step in the process of identifying exporting industrial districts was to group export firms according to the geographical location of their plant. Firms were initially grouped by municipalities, after which point we analyzed the extent to which a single municipality or group of municipalities fell into the category of industrial district. Historical evidence was also taken into account in this identification process. Thus, a municipality or group of municipalities was said to form an industrial district when the available historical evidence confirmed the existence of Marshallian external economies, namely specific but non-codified knowledge, subsidiary industries, and a specialized common labor market. Evidence on the existence of local institutions was also considered. Additionally, it was established that the maximum distance between a municipality and the centre of the district should be approximately twenty-five kilometers. ${ }^{38}$ Although somewhat arbitrary, this geographical limitation was introduced in order to define district borders in a more precise way. Of course, certain requirements regarding the minimum number of firms that had to be concentrated in the territory were also taken into account. Specifically, it was established that the municipality or group of municipalities had to be formed by a minimum of ten exporting firms in textiles, clothing, or shoemaking in order to be considered as an exporting industrial district. It is acknowledged that this decision is somewhat arbitrary.

[Table 2 about here]

[Figure 2 about here]

Using this method, the total number of Spanish textile, clothing, and shoemaking export districts identified for the late 1980s amounts to fourteen (see table 2 and figure 1). In alphabetical order they are Almansa (province of Albacete), Barcelona-Baix Llobregat (Barcelona), Elda (Alacant), Elx (Alacant), Igualada (Barcelona), Inca (Majorca), Madrid (Madrid), Mataró (Barcelona), Olot (Girona), Ontinyent-Alcoi (València, Alacant), Granollers (Barcelona), Sabadell (Barcelona), València (València), and Vic (Barcelona). These can also be considered the fourteen Spanish industrial districts that enjoy a competitive advantage in textiles, apparel, and footwear, since the propensity to export is an indicator of competitiveness. ${ }^{39}$ If we accept that exports reflect a firm's efficiency, then it should also be concluded that these fourteen districts probably included firms with an above-average level of productivity. Table 2 and figure 1 provide additional information about the exporting districts identified. In particular, they show their geographical location, their product specialization, and their importance in terms of number of firms and export values. This information merits a number of comments. Firstly, by the 1980s most of the textile, clothing, and shoemaking export districts were geographically located along the Mediterranean coast of Spain. In fact, this was the area where these economic activities developed, following a process that dates back to the first Industrial Revolution or even earlier.

Secondly, the Spanish industrial districts that, in the 1980s, enjoyed competitive advantage in textiles, apparel, and footwear were far from being homogenous in terms of the number of firms they concentrated and the total value of the products they exported. At the top of the ranking is the household textiles district of Ontinyent-Alcoi. This district had forty-three export firms, which is more than four times the number of export firms found in the cotton textiles district of Olot, which was ranked bottom.

\footnotetext{
${ }^{38}$ Geographically, districts tend to approximate to old counties, which, in Catalonia, were reorganized in the 1930s by considering the main market in which farmers traded their produce.

${ }^{39}$ See, for example, Costa-Campi and Viladecans-Marsal, "The District Effect."
} 
Regarding export values, the Ontinyent-Alcoi district was again ranked first, with total exports amounting to 188 million dollars. This means that total exports in OntinyentAlcoi were seven times higher than in the knitwear district of Igualada, which was the district with the lowest export values.

Of course, this ranking would vary greatly if, instead of taking into account total export values, the average export value per firm was considered. In this case, the leather district of Vic would be ranked first, whereas the footwear district of Inca (Majorca) would be at the bottom. However, cross-district disparities remain even when considering average export values per firm. For example, in the district of Vic the average export value per firm was 6.4 times higher than in the district of Inca (Majorca).

[Table 3 about here]

The final comment on the Spanish textile, clothing, and shoemaking districts that, in the 1980s, enjoyed a competitive advantage must be made for comparative purposes. When these export districts are compared with the local labor markets whose characteristics are those of the neo-Marshallian industrial districts identified by Boix and Galletto using 2001 employment data, then numerous correspondences emerge. For example, eight of the top ten local labor markets were also (or formed part of) export districts. ${ }^{40}$ The same applied to fifteen of the top twenty-three local labor markets (see table 3). However, according to Boix and Galletto, the districts of Barcelona-Baix Llobregat, Madrid, Olot, Granollers, València, and Vic, which we identified as districts with a competitive advantage, do not fall into the category of textile, clothing, and shoemaking industrial districts. Clearly, both methodological and data issues account for most of these differences.

\section{Identifying Marshallian Exporting Districts}

Were the Spanish export districts in textiles, clothing, and shoemaking dominated by small firms? At first glance, it seems plausible that this was the case. Table 4 compares firms' average export values in the fourteen textile, clothing, and shoemaking export districts identified above. These data show that most of the districts were below the export value of the average firm, with only five being above this average (table 4, fourth column). Similarly, only about one-third of all firms had export values above the average firm of the industry (table 4, fifth column). The same trend emerges when we compare firms' export values with the export value of average firms in the district (table 4 , sixth column). These results suggest that small-medium firms also predominated in export districts, as neo-Marshallian scholars would predict.

\section{[Table 4 about here]}

However, the predominance of small- and medium-sized firms alone provides an insufficient basis on which to conclude that during the 1980s the Spanish export districts in textiles, apparel, and footwear should be considered as neo-Marshallian districts. Although they were mostly populated by small-medium firms, it could also be that some medium-large firms accounted for a significant share of total district exports. If this was the case, then the district should be identified as a hub-firm district rather than a neo-Marshallian one.

\footnotetext{
${ }^{40}$ Boix and Galletto, "Sistemas locales."
} 
The only way to know whether this was the case is to calculate concentration coefficients for each of the fourteen export districts identified above. The literature offers a number of coefficients in this regard, although none of them is free from problems. ${ }^{41}$ Two of the most widely used indexes are the concentration ratio (CRr) and the Hirschman-Herfindhal index (HHI). However, the CR4, the HHI, and other concentration indexes are very sensitive to the number of firms operating in a market or industry. Furthermore, they also fail to provide unmistakable information about concentration. Consequently, inequality coefficients are also used in order to overcome the potential shortcomings of concentration indexes. These coefficients are widely used as a measure of inequality of income or wealth distribution, but they are also applied in industrial organization and in studies analyzing the geographical concentration of economic activity.

[Figure 2 about here]

A simple way to measure inequality is to construct deciles in order to determine the share of market, sales, or any other variable that concentrates the chosen 10 percent of firms. The measure of inequality most commonly used by scholars is, however, the Gini coefficient (GC), which ranges between 0 (complete equality) and 1 (complete inequality). Figure 2 and Appendix 1 report these two latter indices for the particular case of Spanish export districts for textiles, apparel, and footwear in 1987. The data in figure 2(a) refer to the share of the top 10 percent of exporting firms in the district's export values, while figure 2(b) shows the GC across export districts. Firm size is proxied by export values, while the firms' market shares are calculated at district level.

The results are revealing. Firstly, they show the existence of a wide range of concentration levels across export districts. For example, between the district with the maximum and the minimum concentration level, a difference of 1:5 is found when using the top 10 percent ratio, as opposed to 1:3 when the GC is applied. Although distances across districts may vary depending on the index used, both measures of inequality generally yield very similar results: export districts at the bottom (or the top) of the concentration ranking derived from the top 10 percent ratio tend to remain in the same position when the GC is estimated.

In addition to the substantial differences in export concentration levels, figure 2 also reveals another key point: in many districts, exports were in the hands of a small number of firms that concentrated a large share of the district's exports. In other words, in the 1980s a large number of Spanish exporting districts in the textile, apparel, and footwear industries corresponded more to the category of hub-firm districts than to the neo-Marshallian one. We are well aware, however, that "in the absence of a theory of concentration it is hard to know what the cut-off is for 'high' concentration."42

\section{[Table 5 about here]}

In interpreting the results obtained with the top 10 percent ratio, we established the arbitrary (though sensitive) cutoff point of a 30-percent export share. ${ }^{43}$ Thus, we consider that an export district falls into the category of a hub-firm district when the top 10 percent of exporting firms account for more than 30 percent of the total district

\footnotetext{
${ }^{41}$ See, for example, Clarke, Industrial Economics.

${ }^{42}$ Berry and Pakes, "Introduction and Stylized Facts," 11.

${ }^{43}$ We accept that the cutoff point we establish has some degree of arbitrariness, but we strongly believe that can be a useful tool to have an empirical definition of hub-firm districts.
} 
export values. Similarly, we also established that export districts with a GC below 0.5 can be considered neo-Marshallian districts. Under these criteria, the use of the top 10 percent ratio indicates that there are eight hub-firm districts, whereas the GC gives a figure of seven (see table 5). ${ }^{44}$

\section{[Table 6 about here]}

In light of the above evidence, one might conclude that in the 1980s about half of the Spanish exporting districts in the textile, apparel, and footwear industries fell into the category of hub-firm districts, with medium-large firms probably acting as coordinators. It is perhaps even more important to note that these hierarchical districts accounted for a substantial share of total district exports (see table 6). Indeed, the value of exports carried out from leading firm districts accounts for at least 67 percent of all export values when the concentration cutoff point is based on the top 10 percent ratio or the GC.

With hierarchical districts accounting for between 65 percent and 75 percent of export values, a further point to consider is why these districts were able to account for such high percentages.

Unfortunately, it is not possible to give a precise answer to this question at the present stage of our research. Nonetheless, one is tempted to hypothesize that hub-firm districts did take advantage of both external and internal economies. Together with the classical Marshallian externalities of the district, they also benefited from technological, managerial, and marketing and distribution capabilities mostly provided by leading firms.

\section{Districts in the Internationalization of "Made in Spain" Fashion: The Role of Inheritance and Leading Firms}

Thus far, we have identified and characterized Spanish export districts for textiles, clothing, and shoemaking based on information referring to 1987, just before the most important "Made in Spain" fashion firms began to internationalize. The question that now needs to be answered is whether the 1980s' exporting industrial districts contributed to the internationalization of what are nowadays the main "Made in Spain" fashion firms. Before tackling this question it will be useful to have an overview of both the process of internationalization of fashion firms and the historical transformation of "fashion export districts."

In recent decades, Spain's textile, apparel, and footwear industries have undergone a strong process of internationalization. Indeed, since the late 1980s the trend in Spanish exports of fashion products has been one of robust growth, and exports have become a major driving force behind the country's main fashion industries. Some studies have estimated that by 2007 exports already accounted for 65 percent of total clothing output, as well as for 96 percent of total footwear output. ${ }^{45}$ In parallel to the growth in exports,

\footnotetext{
44 Apart from these two inequality coefficients, we have also estimated CR4 ratios and HH indexes. Interestingly, they show that the number of hub-firm districts is not so different when these two latter measures of concentration are applied, although the district categorization varies depending on the coefficient used. For further details, see Catalan and Ramon-Muñoz, "The Origins".

45 According to official data, between 1988 and 2008 the export values for textiles, clothing, and shoemaking grew at an annual rate of more than 6 percent at current prices (around 2.5 percent in real
} 
a considerable number of Spanish fashion firms have opened their own retail stores in foreign markets, including the major fashion capitals of Europe. This strategy has not only boosted export expansion but has also contributed to the diffusion and strengthening of some Spanish fashion trademarks abroad. Another dimension of this internationalization process has been the transformation of location patterns. From the early 1990s onwards, the largest Spanish fashion firms have progressively delocalized their production to lower labor cost countries and regions, such as Portugal, northern Africa, and Asia. ${ }^{46}$ Alongside this process the largest Spanish fashion firms have been able to combine brand image with innovative design. ${ }^{47}$

The outcome of this recent internationalization process has been that a considerable number of Spanish firms have been able to penetrate foreign markets. According to the available information, Spanish fashion products are nowadays sold to more than 70 countries, although the bulk of these exports have Europe as their final destination. To give some examples, by 2007 almost 70 percent of all Spanish clothing exports were sent to the European Union. During the same period, the Old Continent also accounted for almost 77 percent of Spanish footwear sales abroad, with France as the major client. $^{48}$

\section{[Figure 3 about here]}

The regional origin of this export trade also reveals a noteworthy level of concentration in Spanish textile, apparel, and footwear exports. By 2006/2007, two single regions accounted for around 60 percent of total exports, while the top four export regions concentrated more than 80 percent of all Spanish textile, clothing, and shoemaking exports. Figure 3 shows the four largest export regions for these industries, which in descending order were Catalonia (35 percent), Galicia (25 percent), Valencia (18 percent), and Madrid ( 7 percent). This geographical distribution of exports needs to be stressed. Leaving aside the case of Galicia, the other three major export regions in 2006/2007 (Catalonia, Valencia, and Madrid) were precisely the regions which, during the 1980s, hosted twelve of the fourteen export districts for textiles, clothing, and shoemaking that have been identified in the preceding sections.

The case of Galicia, which ranks second in the regional export list, merits further comment. In the 1980s, no export districts were identified in this northwestern Spanish region. However, there is clear evidence that around the cities of Redondela, Vigo and Coruña the clothing industry had reached a certain level of development during the 1970s, which suggests that industrial textile districts might have emerged. At all events, during the stagnation crisis (1973-1985), the Galician textile industry underwent a profound transformation. Large firms declined as labor costs rose, whereas more flexible small- and medium-sized firms were able to survive, in part by making use of the Verlagssystem or putting-out system. ${ }^{49}$ Interestingly, one of these firms was owned

terms). Own calculation, derived from Ministerio de Economía y Competitividad, Estadísticas del Comercio Exterior (dataComex).

46 See, for example, the case studies by Alonso, "Vistiendo a 3 continentes"; Manera, Las islas del calzado; Tokatli, "Global Sourcing"; Pla-Barber and Puig, "Is the Influence."

${ }^{47}$ Saviolo and Ravasi, "Business Relations."

${ }^{48}$ Data taken from Instituto Español de Comercio Exterior, "Spanish Fashion in Figures."

49 Carmona and Nadal, El empeño industrial, 368-76. It is worth noting that other districts also experienced significant restructuring prior to the mid-1980s. Barcelona had begun this process in 1969, when its main cotton mill, La España Industrial, closed down. A comparable hub-firm in the wool district of Sabadell, Marcet, followed during the stagnation crisis. During this period, other districts that saw their 
by Amancio Ortega, the founder of Inditex, the company that has become the world's leading textile distribution group. ${ }^{50}$

[Table 7 about here]

Table 7 presents additional evidence on the geographical origins of Spain's current textile, apparel, and footwear products: it indicates the location of the top fashionrelated Spanish firms, which are ranked according to their sales value around $2006 .{ }^{51}$ This table shows that most of the firms under Spanish control in the industries of textiles, apparel, and footwear emerged from Marshallian districts. Thirty-six out of fifty (i.e., 72 percent) of these leading firms in fashion-related industries were established within the fourteen exporting districts listed above.

A second group of firms emerged from districts that were not identified as exporting ones in the late 1980s. There were five such firms in our sample of top fashion-related product sellers. Therefore, 10 percent of today's top fashion firms from Spain were set up in districts with a poor export performance in the moment the country joined the EEC. These firms belonged to the districts of Coruña (Galicia), Fuensalida (Castilla-La Mancha), and Arnedo (Rioja). Inditex, which is currently the world's top retailer of fastfashion products, came from the first of this second type of districts. It should be stressed that Ortega's firm accounted for 49 percent of the sales of the top fifty Spanish fashion-related firms. Instead, it accounted for a much more modest share of the domestic market. It represented 12 percent of the Spanish fashion market in early $2012 .{ }^{52}$ This percentage suggests the very competitive nature of the fashion market, which might have boosted the internationalization of Inditex. Furthermore, and despite the fact that it did not emerge from an exporting district, Ortegas' firm has its roots in an industrial district. This has been already mentioned above. Now, it will be suffice to outline that the districtual nature of Inditex has remained over time. According to data for 2007, about 55 percent of the group's suppliers were still located in Galicia and Northern Portugal, in what can be considered a northwestern Iberian textile hub-firm district. ${ }^{53}$

Finally, only nine of the top fifty fashion-related firms were born out of Marshallian districts. In other words, just 18 percent of today's most important firms in the business of "Made in Spain" fashion did not benefit from original district externalities. In short, one of the main conclusions to be drawn from table 7 is that 82 percent of Spanish firms in fashion-related business benefited from the classical externalities of the Marshallian district. Furthermore, and this is of enormous interest from an evolutionary economics perspective, table 7 shows that at least thirty-one of the entrepreneurs behind the firms in the sample were already in post prior to 1974. Therefore, 62 percent of the top fashion-related firms originated before the end of the Golden Age.

In light of the above evidence, it can be argued that the recent internationalization of Spanish fashion firms was favored by spatial concentration and the external economies

hub-firms collapse were Redondela (Regojo), Vigo (Dresslok), Mataró (Marfá), and Elx (FACASA). Some of these presumably imitated the Galician strategy of outsourcing in order to cope with the crisis.

${ }^{50}$ Alonso, "Vistiendo a 3 continentes"; Alonso, "Competitividad internacional";

O’Shea, Así es Amancio Ortega; Tokatli, "Global Sourcing."

${ }^{51}$ The subsidiaries of foreign fashion firms have been excluded from table 7. Instead, we have included a few local commodity producers such as "La Seda de Barcelona," which used to produce strategic inputs for the districts.

52 Gastesi, "Inditex acapara."

${ }^{53}$ Alonso, "Competitividad internacional." 
of scale that emerged through industry concentration or clustering. However, in parallel to the internationalization of Spanish fashion firms, industrial districts for textiles, clothing, and shoemaking were transformed and, in some cases, declined during the 1990s and early 2000s.

Indeed, until the recession of the early 1990s, exporting districts and internationalized firms went hand in hand. Subsequently, however, they became divorced as increasing deregulation encouraged outsourcing beyond national borders. ${ }^{54}$ In addition, the diffusion of new information and communication technologies enabled mediumlarge firms to become more flexible, thereby eroding a traditional advantage of districts. In this context, fast-fashion began to experience a boom, since new technologies made it possible for firms to know very quickly which products and models their customers preferred, and to ensure shop-shelves were restocked several times per week. Moreover, these technologies also allowed outsourcing very far from the original district: in the case of Spain, this initially meant Portugal, followed by Northern Africa, and, finally, Asia. In short, hub-firms, which had invested in branding, retailing, design, and new technologies, were able to benefit the most from the possibilities of just-in-time fashion, whereas districts had a hard time trying to compete against foreign suppliers with extremely lower labor costs.

The removal of import quotas from China, after its adhesion to the WTO, also ushered in a new period of tremendous erosion of competitive advantage (2001-2009). The Spanish districts experienced a dramatic loss of firms within the traditional textile, apparel, and footwear industries, as well as a generalized reduction in both output and employment. ${ }^{55}$ The resort to massive overseas outsourcing became a common strategy among Spain's fashion-related hub-firms, and the decline of districts seemed difficult to halt. Nevertheless, at a time in which a Galician firm (Inditex) has become the world's leading fashion retailer, it should be stressed that nearly all the top Spanish fashion firms originated within Marshallian districts and, therefore, had benefited to some extent from their classical externalities.

\section{Conclusions}

By the mid-2000s, a remarkable number of Spanish fashion-related firms had succeeded in international markets, and other companies sold a large share of their sales abroad. This process of internationalization began in the late 1980s. But the actors were not new: our results show that around two-thirds of the present top Spanish firms manufacturing fashion-related products were set up before 1974. As both business historians and evolutionary economists argue, inheritance seems to have mattered.

Marshallian externalities also mattered. We found that more than 80 percent of the present leaders in the fashion-related business were nurtured within industrial districts and, therefore, benefited from the classical Marshallian externalities, that is, knowledge spillovers, local suppliers, and qualified labor force. However, these were not the only externalities that favored internationalization. Our research shows that already in the late 1980s there were at least as many neo- Marshallian exporting districts dominated by small firms as there were hub-firm districts coordinated by medium-large companies acting as district leaders.

\footnotetext{
${ }^{54}$ For the particular case of the Majorcan footwear brand Camper, see Manera, Las islas del calzado.

${ }^{55}$ Molina, "Los distritos industriales."
} 
In the light of this evidence, this paper argues that the advantages of flexibility in fashion-related exporting districts were balanced by the organizational capabilities created by certain leading firms, those which had intensively invested in management, marketing, and distribution. During the last two decades, the organizational capabilities of medium-large firms tended to play an increasing role in the internationalization process of the fashion made in Spain. By contrast, the competitive advantage of traditional export districts seems to have eroded over time.

\section{Appendix 1}

Top 10\% Values and GCs in Spanish Export Districts for Textiles, Apparel, and Footwear in 1987

\begin{tabular}{lllll}
\hline Export district & Main industry & Top 10 percent & Gini & Standard deviation \\
\hline Ontinyent-Alcoi & $\begin{array}{l}\text { Household } \\
\text { textiles }\end{array}$ & 34.8 & 0.51 & 5.1 \\
Barcelona-Baix & Apparel & 59.1 & 0.70 & 9.2 \\
$\quad$ Llobregat & & & & \\
Granollers & Leather & 44.2 & 0.61 & 11.0 \\
Madrid & Apparel & 23.1 & 0.51 & 5.9 \\
Elx & Footwear & 31.1 & 0.44 & 3.6 \\
Vic & Leather & 58.7 & 0.71 & 23.6 \\
Sabadell & Wool fabrics & 46.3 & 0.63 & 4.2 \\
Elda & Footwear & 36.7 & 0.49 & 3.6 \\
València & Apparel & 43.7 & 0.65 & 12.9 \\
Mataró & Knitwear & 26.7 & 0.43 & 3.0 \\
Almansa & Footwear & 23.8 & 0.42 & 3.2 \\
Olot & Cotton fabrics & 17.0 & 0.24 & 1.7 \\
Inca & Footwear & 16.3 & 0.43 & 1.7 \\
Igualada & Knitwear & 27.7 & 0.49 & 2.1 \\
& & & & \\
\hline Notes and & See & &
\end{tabular}

Notes and source: See text and footnotes.

\section{Bibliography of Works Cited}

\section{Books}

Amatori, Franco, and Andrea Colli. Business History. Complexities and Comparisons. London and New York: Routledge, 2011.

Bagnasco, Arnaldo. Tre Italie: La problematica territoriale dello sviluppo italiano. Bologna: Il Mulino, 1977.

Becattini, Giacomo, ed. Lo sviluppo economico della Toscana, con particolare riguardo all'industrializzazione leggera. Firenze: IRPET/Guaraldi, 1975.

ed. Mercato e forze locali: il distretto industriale. Bologna: Il Mulino, 1987.

. Il bruco e la farfalla. Prato nel mondo che cambia (1954-1993). Firenze:

Felice Le Monnier, 2000. 
Blaszczyk, Regina Lee, ed. Producing Fashion: Commerce, Culture, and Consumers. Philadelphia: University of Pennsylvania Press, 2008.

Brusco, Sebastiano. Distretti industriali e sviluppo locale. Una raccolta di saggi (19902002). Edizione a cura di A. Natali, M. Russo, and G. Solinas. Bologna: Il Mulino, 2007.

Carmona, Xoán, and Jordi Nadal. El empeño industrial de Galicia. 250 años de historia, 1750-2000. Madrid: Fundación Pedro Barrié de la Maza, 2005.

Catalan, Jordi, José Antonio Miranda, and Ramon Ramon-Muñoz, eds. Distritos y clusters en la Europa del Sur. Madrid: LID Editorial Empresarial, 2011.

Chandler, Alfred D. Scale and Scope: The Dynamics of Industrial Capitalism. Cambridge, MA: Belknap Press, 1990.

- Shaping the Industrial Century. The Remarkable Story of the Evolution of the Modern Chemical and Pharmaceutical Industries. Cambridge, MA: Harvard University Press, 2005.

Chandler, Alfred D., Franco Amatori, and Takashi Hikino, eds. Big Business and the Wealth of Nations. Cambridge: Cambridge University Press, 1997.

Clarke, Roger. Industrial Economics. Oxford and New York: Basil Blackwell, 1985.

Colli, Andrea. Il Quarto Capitalismo. Una prospettiva per il futuro dell'Italia. Venecia: Marsilio, 2002.

Dosi, Giovanni. Technical Change and Industrial Transformation: The Theory and an Application to the Semiconductor Industry. New York: St. Martin's Press, 1984.

Freeman, Christopher. The Economics of Industrial Innovation. Harmondsworth: Penguin, 1974.

Lebot, Florent, and Cédric Perrin, eds. Les chemins de l'industrialisation en Espagne et en France. Les PME et le développement des territoires (XVIIIè-XXIè siècles). Peter Lang: Bruxelles, 2011.

Manera, Carles, ed. Las islas del calzado. Historia económica del sector en Baleares (1200-2000). Palma de Mallorca: Lleonard Muntaner Editor, 2002.

Marshall, Alfred. Principles of Economics. London: Macmillan, 1961 [1st ed. 1890].

Nelson, Richard R., and Sidney G. Winter. An Evolutionary Theory of Economic Change. Cambridge, MA: Harvard University Press, 1982.

O’Shea, Covadonga. Así es Amancio Ortega, el hombre que creó Zara. Madrid: La Esfera de los Libros, 2008.

Piore, Michael J., and Charles F. Sabel. The Second Industrial Divide: Possibilities for Prosperity. New York: Basic Books, 1984.

Porter, Michael E. The Competitive Advantage of Nations. New York: Free Press, 1990.

Scranton, Philip. Endless Novelty: Specialty Production and American Industrialization, 1865-1925. Princeton: Princeton University Press, 1997. 
Teece, David J. Dynamic Capabilities and Strategic Management: Organizing for Innovation and Growth. New York: Oxford University Press, 2009.

Uriu, Robert M. Troubled Industries: Confronting Economic Change in Japan. Ithaca, NY: Cornell University Press, 1996.

\section{Articles and Chapters}

Alonso, Luis. "Vistiendo a 3 continentes: La ventaja competitiva del grupo InditexZara, 1963-1999." Revista de Historia Industrial 18 (2000): 157-82.

. "Competitividad internacional e innovación tecnológica. El grupo Inditex, 1985-2009." In Distritos y clusters en la Europa del Sur, edited by Jordi Catalan, José Antonio Miranda, and Ramon Ramon-Muñoz, 337-65. Madrid: LID Editorial Empresarial, 2011.

Amatori, Franco. "Business History: State of the Art and Controversies." Revista de Historia Industrial 39 (2009): 17-35.

—_. "Business History as History." Business History 51, no. 2 (2009): 143-56.

Bagella, Michele, Leonardo Becchetti, and Simona Sacchi. "The Positive Link between Geographical Agglomeration and Export Intensity: The Engine of Italian Endogenous Growth?" In The Competitive Advantage of Industrial Districts. Theoretical and Empirical Analysis, edited by Michele Bagella and Leonardo Becchetti, 95-126. New York: Physica, 2000.

Becattini, Giacomo. "Dal settore industriale al distretto industriale." Rivista di Economia e Politica Industriale 1 (1979): 1-8.

Becchetti, Leonardo, and Stefania P. S. Rossi. "UE and Non UE Export Performance of Italian Firms. Is There an Industrial District Effect?" In The Competitive Advantage of Industrial Districts. Theoretical and Empirical Analysis, edited by Michele Bagella and Leonardo Becchetti, 127-48. New York: Physica, 2000.

Boix, Rafael. "Los distritos industriales en la Europa Mediterránea: los mapas de Italia y España.” Mediterráneo económico 13 (2008): 161-81.

Boix, Rafael, and Joan Trullén. "Industrial Districts, Innovation and I-district Effect: Territory or Industrial Specialization?" European Planning Studies 18, no. 10 (2010): 1707-29.

Boix, Rafael, and Vittorio Galletto. "Sistemas locales de trabajo y distritos industriales marshallianos en España.” Economía Industrial 359 (2006): 165-84.

"Marshallian Industrial Districts in Spain." Italian Journal of Regional Science 7, no. 3 (2008): 29-52.

Bronzini, Raffaello. "Sistemi produttivi locali e commercio estero: un'analisi territoriale delle esportazioni italiane." In Lo sviluppo locale. Un'indagine della Banca d'Italia sui distretti industriali, edited by Luigi Federico Signorini, 101-22. Corigliano Calabro: Meridiana Libri, 2000. 
Brusco, Sebastiano. "Economie di scala e livello tecnologico nelle piccole imprese." In Crisi e ristrutturazione nell'economia italiana, edited by Augusto Graziani, 530-59. Torino: Einaudi, 1975.

. "The Emilian Model: Productive Decentralisation and Social Integration." Cambridge Journal of Economics 6, no. 2 (1982): 167-84.

Bugamelli, Matteo, and Luigi Infante. "I costi irrecuperabili per l'accesso ai mercati esteri: un ruolo per i distretti industriali?" In Economie locali e competizione globale: il localismo industriale italiano di fronte a nuove slide, edited by Luigi Federico Signorini and Massimo Omiccioli, 211-29. Bologna: Il Mulino, 2005.

Chandler, Alfred D. "Organizational Capabilities and the Economic History of the Industrial Enterprise.” Journal of Economic Perspectives 6, no. 3 (1992): 79-100.

Chandler, Alfred D., and Takashi Hikino. "The Large Industrial Enterprise and the Dynamics of Modern Economic Growth." In Big Business and the Wealth of Nations, edited by Alfred D. Chandler, Franco Amatori, and Takashi Hikino, 24-57. Cambridge: Cambridge University Press, 1997.

Cimoli, Mario, Giovanni Dosi, and Joseph E. Stiglitz. "The Political Economy of Capabilities Accumulation. The Past and Future of Policies for Industrial Development." In Industrial Policy and Development. The Political Economy of Capabilities Accumulation, edited by Mario Cimoli, Giovanni Dosi, and Joseph E. Stiglitz, 1-16. Oxford: Oxford University Press, 2009.

Costa-Campi, Teresa M., and Elisabet Viladecans-Marsal. "The District Effect and the Competitiveness of Manufacturing Companies in Local Productive Systems." Urban Studies 36, no. 12 (1999): 2085-98.

Crestanello, Paolo, and Giuseppe Tattara. "A Global Network and its Local Ties. Restructuring of the Benetton Group." In Internationalization, Technological Change and the Theory of the Firm, edited by Nicola De Liso and Riccardo Leoncini, 239-58. London and New York: Routledge, 2010.

Dei Ottati, Gabi. "Trust, Interlinking Transactions and Credit in the Industrial District." Cambridge Journal of Economics 18, no. 6 (1994): 529-46.

"Exit, Voice and the Evolution of Industrial Districts: The Case of the PostWorld War II Economic Development of Prato." Cambridge Journal of Economics 27, no. 4 (2003): 501-22.

"El 'efecto distrito': algunos aspectos conceptuales de sus ventajas competitivas.” Economía Industrial 359 (2006): 73-87.

Dosi, Giovanni, Richard R. Nelson, and Sidney G. Winter. "The Nature and Dynamics of Organizational Capabilities." In The Nature and Dynamics of Organizational Capabilities, edited by Giovanni Dosi, Richard R. Nelson, and Sidney G. Winter, 122. Oxford: Oxford University Press, 2000.

Freeman, Christopher. "The 'Nations System of Innovation' in Historical Perspective." Cambridge Journal of Economics 19, no. 1 (1995): 5-24.

Gastesi, Aintzane. "Inditex acapara el 12\% de la quota de mercat de la moda a Espanya." La Vanguardia 20 (September 2012): 57. 
Gola, Carlo, and Alessandra Mori. "Concentrazione spaziale della produzione e specializzazione internazionale dell'industria italiana." In Lo sviluppo locale. Un'indagine della Banca d'Italia sui distretti industriali, edited by Luigi Federico Signorini, 67-100. Corigliano Calabro: Meridiana Libri, 2000.

Klepper, Steven. "The Origin and Growth of Industry Clusters: The Making of Silicon Valley and Detroit." Journal of Urban Economics 67, no. 1 (2010): 15-32.

Klepper, Steven, and Kenneth L. Simons. "Dominance by Birthright: Entry of Prior Radio Producers and Competitive Ramifications in the U.S. Television Receiver Industry." Strategic Management Journal 21, no. 10-11 (2000): 997-1016.

Lazerson, Mark H., and Gianni Lorenzoni. "The Firms that Feed Industrial Districts: A Return to the Italian Source." Industrial and Corporate Change 8, no. 2 (1999): 23566.

Lazonick, William, and David J. Teece. "Introduction: Management InnovationEssays in the Spirit of Alfred D. Chandler, Jr." Industrial and Corporate Change 19, no. 2 (2010): 295-96.

Llonch, Montserrat. "Trademarks, Product Differentiation and Competitiveness in the Catalan Knitwear Districts during the Twentieth Century." Business History 54, no. 2 (2012): 179-200.

Markusen, Ann. "Sticky Places in Slippery Space: A Typology of Industrial Districts." Economic Geography 72, no. 3 (1996): 293-313.

Martín Aceña, Pablo, and María Ángeles Pons. "Sistema monetario y financiero." In Estadísticas históricas de España. Siglos XIX-XX. Volumen II, edited by Albert Carreras and Xavier Tafunell, 645-706. Bilbao: Fundación BBVA, 2005.

Merlo, Elisabetta. "Italian Fashion Business: Achievements and Challenges (1970s2000s)." Business History 53, no. 3 (2011): 344-62.

Merlo, Elisabetta, and Francesca Polesse. "Turning Fashion into Business: The Emergence of Milan as an International Hub." Business History Review 80, no. 3 (2006): 415-47.

Molina, Xavier F. "European Industrial Districts: Influence of Geographic Concentration on Performance of the Firm." Journal of International Management 7 (2001): 1-18.

- "Los distritos industriales en la Europa Mediterránea: las diferencias entre Italia y España.” Mediterráneo económico 13 (2008): 183-201.

Nelson, Richard R., and Sidney G. Winter. "Evolutionary Theorizing in Economics." Journal of Economic Perspectives 16, no. 2 (2002): 23-46.

Pla-Barber, José, and Francisco Puig. "Is the Influence of the Industrial District on International Activity Being Eroded by Globalization? Evidence from a Traditional Manufacturing Industry.” International Business Review 18, no. 7 (2009): 435-45.

Polese, Francesca, and Regina Lee Blaszczyk. "Fashion Forward: The Business History of Fashion.” Business History 54, no. 1 (2012): 6-9.

Popp, Andrew, and John F. Wilson. "The Emergence of Industrial Districts in Industrialising England, 1750-1914." In A Handbook of Industrial Districts, edited 
by Giacomo Becattini, Marco Bellandi, and Lisa De Propris, 43-57. Cheltenham: Edward Elgar, 2009.

Porter, Michael E. "Clusters and the New Economics of Competition." Harvard Business Review 76, no. 6 (1998): 77-90.

Porter, Michael E., and Christian Ketels. "Clusters and Industrial Districts: Common Roots, Different Perspectives." In A Handbook of Industrial Districts, edited by Giacomo Becattini, Marco Bellandi, and Lisa De Propris, 172-86. Cheltenham: Edward Elgar, 2009.

Ramazzotti, Paolo. "Industrial District, Social Cohesion and Economic Decline in Italy." Cambridge Journal of Economics 34, no. 6 (2010): 955-74.

Rinaldi, Alberto. "The Emilian Model Revisited: Twenty Years After." Business History 47, no. 2 (2005): 244-66.

Scranton, Philip. "Beyond Chandler." Enterprise and Society 9, no. 3 (2008): 426-29.

Sforzi, Fabio. "L'identificazione spaziale." In Mercato e forze locali: il distretto industriale, edited by Giacomo Becattini, 143-67. Bologna: Il Mulino, 1987.

Signorini, Luigi Federico. "The Price of Prato, or Measuring the Industrial District Effect.” Papers in Regional Science 73, no. 4 (1994): 369-92.

Soler, Vicent. "Verificación de las hipótesis del distrito industrial. Una aplicación al caso valenciano." Economía Industrial 334 (2000): 13-23.

Teece, David J., Gary Pisano, and Amy Shuen. "Dynamic Capabilities and Strategic Management.” Strategic Management Journal 18, no. 7 (1997): 509-33.

Tokatli, Nebahat. "Global Sourcing: Insights from the Global Clothing Industry-The Case of Zara, a Fast Fashion Retailer." Journal of Economic Geography 8, no. 1 (2008): 21-38.

Tolliday, Steven, et al. "Scale and Scope: A Review Colloquium." Business History Review 64, no. 4 (1990): 690-735.

Trullén, Joan. "Distritos industriales marshallianos y sistemas locales de gran empresa en el diseño de una nueva estrategia para el crecimiento de la productividad en la economía española." Economía Industrial 359 (2006): 95-112.

Wilson, John F., and Andrew Popp. "Conclusion." In Industrial Clusters and Regional Business Networks in England 1750-1970, edited by John F. Wilson and Andrew Popp, 271-82. Aldershot: Ashgate, 2003.

Zeitlin, Jonathan. "Industrial Districts and Regional Clusters." In The Oxford Handbook of Business History, edited by Geoffrey Jones and Jonathan Zeitlin, 219-43. Oxford: Oxford University Press, 2008.

Newspapers, Magazines, and Yearbooks

Fomento de la Producción. Barcelona, 1988.

Anuario Estadístico de España. Madrid: Instituto Nacional de Estadística, 1989. 


\section{Unpublished Materials}

Berry, Steven, and Ariel Pakes. "Introduction and Stylized Facts from Empirical Models of Firms and Markets." Unpublished paper, 2003.

Boix, Rafael, and Vittorio Galletto. "The New Map of the Industrial Districts in Spain and the Comparison with Italy and the United Kingdom: Improving International Comparison of Industrial Districts with Common Methodologies." Paper presented at the Regional Studies Association International Conference, Lisbon, 2-5 April 2007.

Catalan, Jordi, and Ramon Ramon-Muñoz. "The Origins of 'Made in Spain' Fashion. The Competitive Advantage of the Textile, Apparel and Footwear Districts since the Golden Age." Documents de Treball de la Facultat d'Economia i Empresa. Col.lecció Economia. Universitat de Barcelona, E11/265, 2011.

Saviolo, Stefania, and Davide Ravasi, eds. "Business Relations in the EU Clothing Chain: From Industry to Retail and Distribution." Report prepared by the Bocconi University, ESSEC Business School and Baker \& McKenzie for the European Commission, 2007.

\section{Electronic Sources}

Instituto Español de Comercio Exterior (ICEX). "Spanish Fashion in Figures." http://www.fashionfromspain.com.

Ministerio de Economía y Competitividad. "Estadísticas del Comercio Exterior." http://datacomex.comercio.es.

Sistema de Análisis de Balances Ibéricos. "SABI database." http://www.sabi.bvdep.com/. 


\section{Tables and figures}

Table 1. Neo-Marshallian industrial districts and employees in textiles, apparel, and footwear (Spain, 2001)

\begin{tabular}{llll}
\hline Indicators & $\begin{array}{l}\text { Textile and apparel } \\
\text { products }\end{array}$ & $\begin{array}{l}\text { Leather and } \\
\text { footwear }\end{array}$ & $\begin{array}{l}\text { Subtotal } \\
(1)+(2)\end{array}$ \\
\hline $\begin{array}{l}\text { Number of industrial districts } \\
\text { As percent of total Spanish } \\
\quad \text { industrial districts }\end{array}$ & 46 & 23 & 69 \\
$\begin{array}{l}\text { Number of employees in the } \\
\text { industrial district }\end{array}$ & 136,324 & 11.2 & 33.6 \\
$\begin{array}{l}\text { As percent of total Spanish } \\
\quad \text { industrial districts }\end{array}$ & 14.2 & 83,808 & 220,132 \\
$\begin{array}{l}\text { As percent of sector } \\
\text { Number of employees in } \\
\quad \text { the main industry of the } \\
\text { industrial district }\end{array}$ & 50.4 & 8.8 & 23.0 \\
$\begin{array}{l}\text { As percent of the main } \\
\text { industries in total Spanish } \\
\text { industrial districts }\end{array}$ & 85,064 & 85.2 & 59.7 \\
\hline
\end{tabular}

Source: Own elaboration from Boix, "Los distritos industrials," 169. 
Table 2. Spanish exporting industrial districts for textiles, apparel, and footwear in 1987

\begin{tabular}{|c|c|c|c|c|c|c|}
\hline \multirow[b]{2}{*}{ District } & \multirow{2}{*}{$\begin{array}{l}\text { County or community } \\
\text { of municipalities }\end{array}$} & \multirow[b]{2}{*}{ Province/region } & \multirow[b]{2}{*}{ Main industry } & \multirow{2}{*}{$\begin{array}{l}\text { Number of } \\
\text { export firms }\end{array}$} & \multicolumn{2}{|c|}{$\begin{array}{l}\text { Export values } \\
\text { (million dollars) }\end{array}$} \\
\hline & & & & & Total & Per firm \\
\hline Ontinyent and Alcoi & Vall d'Albaida-Alcoià & València-Alacant/VAL & Household textiles & 43 & 188.0 & 4.4 \\
\hline $\begin{array}{l}\text { Barcelona and Baix } \\
\text { Llobregat }\end{array}$ & $\begin{array}{l}\text { Barcelonès-Baix } \\
\text { Llobregat }\end{array}$ & Barcelona/CAT & Synthetic fibres & 39 & 181.7 & 4.7 \\
\hline Granollers & Vallès Oriental & Barcelona/CAT & Leather & 22 & 160.0 & 7.3 \\
\hline Madrid & - & Madrid/MAD & Clothing & 25 & 158.0 & 6.3 \\
\hline Elx & Baix Vinalopó & Alacant/VAL & Footwear & 39 & 151.3 & 3.9 \\
\hline Vic & Osona & Barcelona/CAT & Leather & 10 & 131.1 & 13.1 \\
\hline Sabadell & Vallès Occidental & Barcelona/CAT & Wool fabrics & 44 & 120.6 & 2.7 \\
\hline Elda & Vinalopó Mitjà & Alacant/VAL & Footwear & 36 & 120.2 & 3.3 \\
\hline València & València & València/VAL & Clothing & 15 & 114.8 & 7.7 \\
\hline Mataró & Maresme & Barcelona/CAT & Knitwear & 26 & 101.0 & 3.9 \\
\hline Almansa & $\begin{array}{l}\text { Monte Ibérico-Corredor } \\
\text { de Almansa }\end{array}$ & Albacete/CMAN & Footwear & 15 & 55.0 & 3.7 \\
\hline Olot & Garrotxa & Girona/CAT & Cotton fabrics & 10 & 38.2 & 3.8 \\
\hline Inca & El Raiguer & Mallorca/BAL & Footwear & 14 & 28.6 & 2.0 \\
\hline Igualada & Anoia & Barcelona/CAT & Knitwear & 12 & 25.6 & 2.1 \\
\hline Total & & & & 350 & $1,574.0$ & 4.5 \\
\hline
\end{tabular}

Abbreviations: BAL: Balearic Islands; CAT: Catalonia; CMAN: Castilla-La Mancha; MAD: Madrid; VAL: València.

Notes and source: Original export values in current pesetas have been converted to 1987 US dollars by using the exchange rate reported by Martín Aceña and Pons, "Sistema monetario," 707. See also text and footnotes. 
Table 3. The top neo-Marshallian Spanish districts for textiles, apparel, and footwear in 2001 when using employment data and Sforzi-ISTAT methodology

\begin{tabular}{|c|c|c|c|c|c|}
\hline District & $\begin{array}{l}\text { County or } \\
\text { community of } \\
\text { municipalities }\end{array}$ & Province/region & $\begin{array}{l}\text { Main } \\
\text { industry }\end{array}$ & $\begin{array}{l}\text { Employees } \\
\text { (number) }\end{array}$ & $\begin{array}{l}\text { Were they } \\
\text { also export } \\
\text { districts in } \\
\text { the } 1980 \text { s? }\end{array}$ \\
\hline Elx & Baix Vinalopó & Alacant/VAL & $\mathrm{LF}$ & 27,141 & Yes \\
\hline Sabadell & $\begin{array}{l}\text { Vallès } \\
\text { Occidental }\end{array}$ & Barcelona/CAT & TC & 21,468 & Yes \\
\hline Elda & Vinalopó Mitjà & Alacant/VAL & $\mathrm{LF}$ & 14,568 & Yes \\
\hline Mataró & Maresme & Barcelona/CAT & $\mathrm{TC}$ & 11,670 & Yes \\
\hline Igualada & Anoia & Barcelona/CAT & TC & 6,262 & Yes \\
\hline Ontinyent & Vall d'Albaida & València/VAL & $\mathrm{TC}$ & 5,612 & $Y_{e s}{ }^{a}$ \\
\hline Alcoi & Alcoià & Alacant/VAL & TC & 3,707 & $Y_{e s}{ }^{a}$ \\
\hline $\begin{array}{c}\text { Talavera de } \\
\text { la Reina }\end{array}$ & - & Toledo/CMAN & TC & 3,690 & No \\
\hline Manresa & Bages & Barcelona/CAT & TC & 3,678 & No \\
\hline Villena & Alt Vinalopó & Alacant/VAL & $\mathrm{LF}$ & 3,646 & Yes $^{\mathrm{b}}$ \\
\hline Calella & Maresme & Barcelona/CAT & $\mathrm{TC}$ & 3,525 & No \\
\hline Almansa & $\begin{array}{l}\text { Monte Ibérico- } \\
\text { Corredor de } \\
\text { Almansa }\end{array}$ & Albacete/CMAN & $\mathrm{LF}$ & 3,491 & Yes \\
\hline Ubrique & Sierra de Cádiz & Cádiz/AND & $\mathrm{LF}$ & 2,828 & No \\
\hline Arnedo & Arnedo & La Rioja & $\mathrm{LF}$ & 2,795 & No \\
\hline Cocentaina & Comtat & Alacant/VAL & TC & 2,349 & Yes $^{\mathrm{b}}$ \\
\hline Crevillent & Baix Vinalopó & Alacant/VAL & $\mathrm{LF}$ & 1,988 & Yes $^{c}$ \\
\hline Monòver & Vinalopó Mitjà & Alacant/VAL & $\mathrm{LF}$ & 1,973 & $Y_{e s}{ }^{b}$ \\
\hline Fuensalida & Torrijos & Toledo/CMAN & $\mathrm{LF}$ & 1,849 & No \\
\hline Xàtiva & Costera & València/VAL & $\mathrm{TC}$ & 1,845 & No \\
\hline Catral & Baix Segura & Alacant/VAL & $\mathrm{LF}$ & 1,795 & No \\
\hline Inca & El Raiguer & Mallorca/BAL & $\mathrm{LF}$ & 1,642 & Yes \\
\hline $\begin{array}{c}\text { Banyeres de } \\
\text { Mariola }\end{array}$ & Alcoià & Alacant/VAL & TC & 1,634 & $Y_{e s}^{a}$ \\
\hline Sax & Alt Vinalopó & Alacant/VAL & $\mathrm{LF}$ & 1,574 & Yes $^{\mathrm{c}}$ \\
\hline
\end{tabular}

Abbreviations: BAL: Balearic Islands; CAT: Catalonia; CMAN: Castilla-La Mancha; MAD: Madrid; VAL: Valencia; LF: Leather and footwear; T: Textiles, TC: Textile, knitwear, and clothing.

Notes: ${ }^{a}$ included in the export district of Ontinyent-Alcoi; bincluded in the export district of

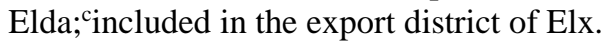

Source: Boix and Galletto, "Sistemas locales," 179-83. 
Table 4. Average export size of firms in the Spanish export districts for textiles, apparel, and footwear in 1987

\begin{tabular}{|c|c|c|c|c|c|}
\hline \multirow[b]{2}{*}{ District } & \multirow{2}{*}{$\begin{array}{l}\text { Main } \\
\text { industry }\end{array}$} & \multirow{2}{*}{$\begin{array}{l}\text { Number of } \\
\text { export firms }\end{array}$} & \multirow{2}{*}{$\begin{array}{l}\text { Export values } \\
\text { per firm } \\
\text { (million dollars) }\end{array}$} & \multicolumn{2}{|c|}{$\begin{array}{l}\text { Percentage of firms } \\
\text { below the average } \\
\text { export value of the }\end{array}$} \\
\hline & & & & Industry & District \\
\hline Ontinyent-Alcoi & $\begin{array}{l}\text { Household } \\
\text { textiles }\end{array}$ & 43 & 4.4 & 69.8 & 69.8 \\
\hline $\begin{array}{c}\text { Barcelona-Baix } \\
\text { Llobregat }\end{array}$ & Apparel & 39 & 4.7 & 74.4 & 76.9 \\
\hline Granollers & Leather & 22 & 7.3 & 54.5 & 77.3 \\
\hline Madrid & Apparel & 25 & 6.3 & 52.0 & 60.0 \\
\hline Elx & Footwear & 39 & 3.9 & 69.2 & 53.8 \\
\hline Vic & Leather & 10 & 13.1 & 50.0 & 70.0 \\
\hline Sabadell & $\begin{array}{l}\text { Wool } \\
\text { fabrics }\end{array}$ & 44 & 2.7 & 81.8 & 79.5 \\
\hline Elda & Footwear & 36 & 3.3 & 75.0 & 66.7 \\
\hline València & Apparel & 15 & 7.7 & 60.0 & 80.0 \\
\hline Mataró & Knitwear & 26 & 3.9 & 57.7 & 50.0 \\
\hline Almansa & Footwear & 15 & 3.7 & 73.3 & 66.7 \\
\hline Olot & $\begin{array}{l}\text { Cotton } \\
\text { fabrics }\end{array}$ & 10 & 3.8 & 60.0 & 50.0 \\
\hline Inca & Footwear & 14 & 2.0 & 92.9 & 64.3 \\
\hline Igualada & Knitwear & 12 & 2.1 & 83.3 & 58.3 \\
\hline Total & & 350 & 4.5 & 69.4 & 67.1 \\
\hline
\end{tabular}

Notes and source: See table 2, text, and footnotes. 
Table 5. Hub-firms (H) and neo-Marshallian (NM) Spanish export districts for textiles, apparel, and footwear in 1987

\begin{tabular}{llll}
\hline & Main industry & $\begin{array}{l}\text { Top 10 } \\
\text { percent } \geq 30 \\
\text { percent }\end{array}$ & $\mathrm{Gl} \geq 0.5$ \\
\hline Ontinyent-Alcoi & Household textiles & $\mathrm{H}$ & $\mathrm{H}$ \\
Barcelona-Baix Llobregat & Apparel & $\mathrm{H}$ & $\mathrm{H}$ \\
Granollers & Leather & $\mathrm{H}$ & $\mathrm{H}$ \\
Madrid & Apparel & $\mathrm{NM}$ & $\mathrm{H}$ \\
Elx & Footwear & $\mathrm{H}$ & $\mathrm{NM}$ \\
Vic & Leather & $\mathrm{H}$ & $\mathrm{H}$ \\
Sabadell & Wool fabrics & $\mathrm{H}$ & $\mathrm{H}$ \\
Elda & Footwear & $\mathrm{H}$ & $\mathrm{NM}$ \\
València & Apparel & $\mathrm{H}$ & $\mathrm{H}$ \\
Mataró & Knitwear & $\mathrm{NM}$ & $\mathrm{NM}$ \\
Almansa & Footwear & $\mathrm{NM}$ & $\mathrm{NM}$ \\
Olot & Cotton fabrics & $\mathrm{NM}$ & $\mathrm{NM}$ \\
Inca & Footwear & $\mathrm{NM}$ & $\mathrm{NM}$ \\
Igualada & Knitwear & $\mathrm{NM}$ & $\mathrm{NM}$ \\
Total number of H districts & & 8 & 7 \\
Total number of NM districts & & 6 & 7 \\
\hline
\end{tabular}

Notes and source: See table 2, text, and footnotes. 
Table 6. Hub-firm and neo-Marshallian districts in the export trade of Spanish textile, apparel, and footwear industries in $\mathbf{1 9 8 7}$

\begin{tabular}{|c|c|c|}
\hline Typology of export districts & $\begin{array}{l}\text { Top } 10 \\
\text { percent } \geq 30 \\
\text { percent }\end{array}$ & $\mathrm{GI} \geq 0.5$ \\
\hline \multicolumn{3}{|l|}{ Panel 1: Hub-firm districts } \\
\hline $\begin{array}{l}\text { Number of districts (as percent } \\
\text { of total export districts) }\end{array}$ & $8(57.1)$ & $7(50.0)$ \\
\hline $\begin{array}{l}\text { Number of firms (as percent of } \\
\text { total export firms) }\end{array}$ & 248 (70.9) & $198(56.6)$ \\
\hline $\begin{array}{l}\text { Total export values (as percent } \\
\text { of total export values) }\end{array}$ & $1,167.6(74.2)$ & $1,054.1(67.0)$ \\
\hline $\begin{array}{l}\text { Average export values per firm } \\
\text { (export values of the average } \\
\text { firm }=100)\end{array}$ & $4.7(104.7)$ & $5.3(118.4)$ \\
\hline \multicolumn{3}{|l|}{ Panel 2: Neo-Marshallian districts } \\
\hline $\begin{array}{l}\text { Number of districts (as percent } \\
\text { of total export districts) }\end{array}$ & $6(42.9)$ & $7(50.0)$ \\
\hline $\begin{array}{l}\text { Number of firms (as percent of } \\
\text { total export firms) }\end{array}$ & $102(29.1)$ & $152(43.4)$ \\
\hline $\begin{array}{l}\text { Total export values (as percent } \\
\text { of total export values) }\end{array}$ & $406.4(25.8)$ & $519.9(33.0)$ \\
\hline $\begin{array}{l}\text { Average export values per firm } \\
\text { (export values of the average } \\
\text { firm }=100)\end{array}$ & $4.0(88.6)$ & $3.4(76.1)$ \\
\hline
\end{tabular}

Notes and source: See table 2, text, and footnotes. 
Table 7. From industrial districts to fashion clusters: leading firms and their origins

\begin{tabular}{|c|c|c|c|c|c|c|}
\hline & Firm & Activity & Origins & $\begin{array}{l}\text { Sales } 2006 \\
(\text { million } €)\end{array}$ & $\begin{array}{l}\text { Did the firm emerge from a } \\
1980 \text { 's industrial district? }\end{array}$ & District \\
\hline 1 & $\begin{array}{l}\text { Industria de Diseño Textil, } \\
\text { S.A. (Inditex) }\end{array}$ & Fast-fashion retailer & 1963 & $6.740,8$ & $\begin{array}{l}\text { Yes, but not from an exporting } \\
\text { district }\end{array}$ & Coruña \\
\hline 2 & Cortefiel, S.A. & Fashion retailer & 1880-1933 & $1.041,0$ & Yes, from an exporting district & Madrid \\
\hline 3 & $\begin{array}{l}\text { Mango MNG Holding, S.L. } \\
\text { (Mango) }\end{array}$ & Fast-fashion retailer & c1968-1984 & 942,0 & Yes, from an exporting district & Sabadell \\
\hline 4 & La Seda de Barcelona & Synthetic fibers and polymers & 1925 & 644,5 & Yes, from an exporting district & Barcelona \\
\hline 5 & Corte Inglés/Induyco +Sfera & Apparel and fashion retailer & 1934 & 634,7 & Yes, from an exporting district & Madrid \\
\hline 6 & Camper-Coflusa & Footwear fashion and retailing & 1877-1975 & 374,3 & Yes, from an exporting district & Inca \\
\hline 7 & Tavex Algodonera, S.A. & $\begin{array}{l}\text { Cotton fabrics, apparel, and } \\
\text { household textiles }\end{array}$ & 1846 & 248,6 & No & - \\
\hline 8 & Adolfo Domínguez, S.A. & Fashion creator and retailer & 1973 & 165,2 & No & - \\
\hline 9 & $\begin{array}{l}\text { Dogi International } \\
\text { Fabrics, S.A. }\end{array}$ & No woven fabrics & 1954 & 137,0 & Yes, from an exporting district & Mataró \\
\hline 10 & $\begin{array}{l}\text { Sociedad Textil Lonia, } \\
\text { S.A. (Stl) }\end{array}$ & Fashion creator and retailer & 1997 & 135,6 & No & - \\
\hline 11 & Anglés Textil, S.A. (Antex) & Yarn spinning & 1968 & 127,9 & No & - \\
\hline 12 & Comdipunt & Apparel retailing & 1998 & 123,2 & Yes, from an exporting district & Mataró \\
\hline 13 & Ubesol, S.L. & Household textiles & 1979 & 121,2 & Yes, from an exporting district & Ontinyent-Alcoi \\
\hline 14 & Punt Roma & Fashion retailing & 1997 & 121,2 & Yes, from an exporting district & Mataró \\
\hline 15 & Armand Basi, S.A. & Fashion creator and retailer & 1948 & 114,9 & Yes, from an exporting district & Mataró \\
\hline 16 & Mayoral Moda Infantil, S.A. & Children's fashion & 1941 & 109,2 & Yes, from an exporting district & Madrid \\
\hline 17 & Sport Street & Footwear retailing & 1994 & 105,8 & Yes, from an exporting district & Madrid \\
\hline 18 & Sedatext & Textile fabrics & 1940 & 100,6 & Yes, from an exporting district & Barcelona \\
\hline
\end{tabular}


Table Continued

\begin{tabular}{|c|c|c|c|c|c|c|}
\hline & Firm & Activity & Origins & $\begin{array}{l}\text { Sales } 2006 \\
(\text { million } €)\end{array}$ & $\begin{array}{l}\text { Did the firm emerge from a } \\
1980 \text { 's industrial district? }\end{array}$ & District \\
\hline 19 & Giró GHS & $\begin{array}{l}\text { Textiles fabrics and } \\
\text { distribution }\end{array}$ & 1994 & 99,4 & Yes, from an exporting district & Mataró \\
\hline 20 & Textil Santanderina & Cotton fabrics & 1960 & 96,4 & No & - \\
\hline 21 & Merkal Calzado & Footwear & 2003 & 96,3 & Yes, from an exporting district & Barcelona \\
\hline 22 & Pronovias, S.L. & Wedding wear & 1964 & 92,4 & Yes, from an exporting district & Barcelona \\
\hline 23 & Caramelo, S.A. & Fashion creator and retailer & 1969 & 73,7 & $\begin{array}{l}\text { Yes, but not from an exporting } \\
\text { district }\end{array}$ & Coruña \\
\hline 24 & Sáez Merino, S.A. & Outwear & $1960 c$ & 70,0 & Yes, from an exporting district & València \\
\hline 25 & Marie Claire, S.A. & Knitted outwear & 1907 & 67,1 & No & - \\
\hline 26 & Julián Rus Canibano & Apparel retailing & 1996 & 66,5 & No & - \\
\hline 27 & Elastómeros Riojanos & Footwear rubber parts & 1972 & 66,3 & $\begin{array}{l}\text { Yes, but not from an exporting } \\
\text { district }\end{array}$ & Arnedo \\
\hline 28 & José Royo, S.L. & Textile fabrics and retailing & 1976 & 65,5 & Yes, from an exporting district & València \\
\hline 29 & SATI Grupo Textil S.A. & No woven fabrics & 1956 & 61,4 & Yes, from an exporting district & Granollers \\
\hline 30 & Pikolino's Interncontinental & Footwear & 1984 & 61,1 & Yes, from an exporting district & Elx \\
\hline 31 & Colortex 1967 SL & Finishers of textiles & 1967 & 54,5 & Yes, from an exporting district & Ontinyent-Alcoi \\
\hline 32 & Colomer Munmany & Leather and apparel & 1792 & 48,7 & Yes, from an exporting district & Vic \\
\hline 33 & Ródenas y Rivera & No woven fabrics & 1972 & 46,4 & No & - \\
\hline 34 & Industrias Murtra, S.A. & Yarn, tapes and fabrics & 1897 & 45,2 & Yes, from an exporting district & Granollers \\
\hline 35 & Puig (Fashion division) & Fashion retailer & 1914 & 50,9 & Yes, from an exporting district & Barcelona \\
\hline 36 & La Doma SA de Curtidos & Leather & 1985 & 48,7 & Yes, from an exporting district & Vic \\
\hline 37 & Estebanell y Pahisa & Household textiles & 1927 & 45,4 & Yes, from an exporting district & Vic \\
\hline 38 & Iriarte Trading Fashion & Apparel and retailing & 1991 & 42,2 & Yes, from an exporting district & Madrid \\
\hline
\end{tabular}


Table Continued

\begin{tabular}{|c|c|c|c|c|c|c|}
\hline & Firm & Activity & Origins & $\begin{array}{l}\text { Sales } 2006 \\
\text { (million } € \text { ) }\end{array}$ & $\begin{array}{l}\text { Did the firm emerge from a } \\
1980 \text { 's industrial district? }\end{array}$ & District \\
\hline 39 & $\begin{array}{l}\text { Sprinter Megacentros del } \\
\text { Deporte }\end{array}$ & Footwear retailing & 1999 & 41,8 & Yes, from an exporting district & Elx \\
\hline 40 & Antecuir & Household textiles & 1989 & 39,6 & Yes, from an exporting district & Ontinyent-Alcoi \\
\hline 41 & Emboga & Footwear retailing & 1988 & 37,7 & Yes, from an exporting district & Elda \\
\hline 42 & Velamen & Textile bags & 1971 & 37,5 & Yes, from an exporting district & Barcelona \\
\hline 43 & Joma Sport & Footwear & 1975 & 37,2 & $\begin{array}{l}\text { Yes, but not from an exporting } \\
\text { district }\end{array}$ & Fuensalida \\
\hline 44 & Cadena & Apparel & 1961 & 36,2 & Yes, from an exporting district & Madrid \\
\hline 45 & Roberto Verino Difusión, S.A. & Fashion creator and retailer & $1982 c$ & 35,5 & No & - \\
\hline 46 & Viscocel & Synthetic fibers & 2000 & 35,5 & Yes, from an exporting district & Madrid \\
\hline 47 & Calzados Pablo & Footwear & 1975 & 34,9 & $\begin{array}{l}\text { Yes, but not from an exporting } \\
\text { district }\end{array}$ & Fuensalida \\
\hline 48 & Industrias Valls & Knitted outwear & $1945 c$ & 32,0 & Yes, from an exporting district & Igualada \\
\hline 49 & Abasic, S.L. & Fashion creator and retailer & 1984 & 29,8 & Yes, from an exporting district & Barcelona \\
\hline 50 & Blue Tower, S.L. & Fashion creator and retailer & $1980 c$ & 28,5 & Yes, from an exporting district & Barcelona \\
\hline
\end{tabular}

Notes and source: See table 2, text, and footnotes 
Figure 1. Spanish exporting industrial districts for textiles, apparel, and footwear in 1987

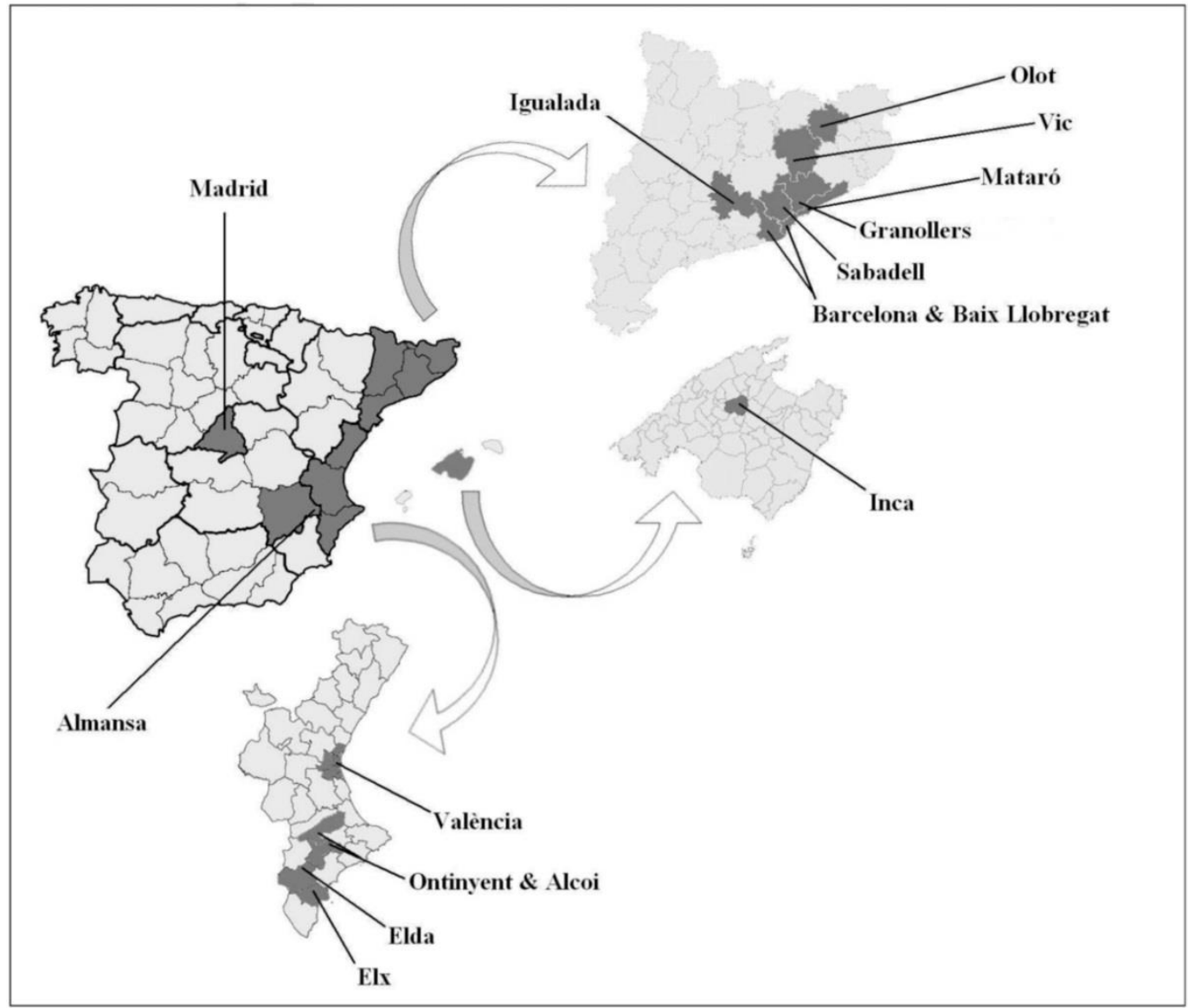

Notes and source: See table 2. 
Figure 2. Concentration and inequality measures in the Spanish export districts for textiles, apparel, and footwear in 1987: (a) The top 10 percent of exporting firms; (b) Gini coefficient.

(a) The top 10\% of exporting firms

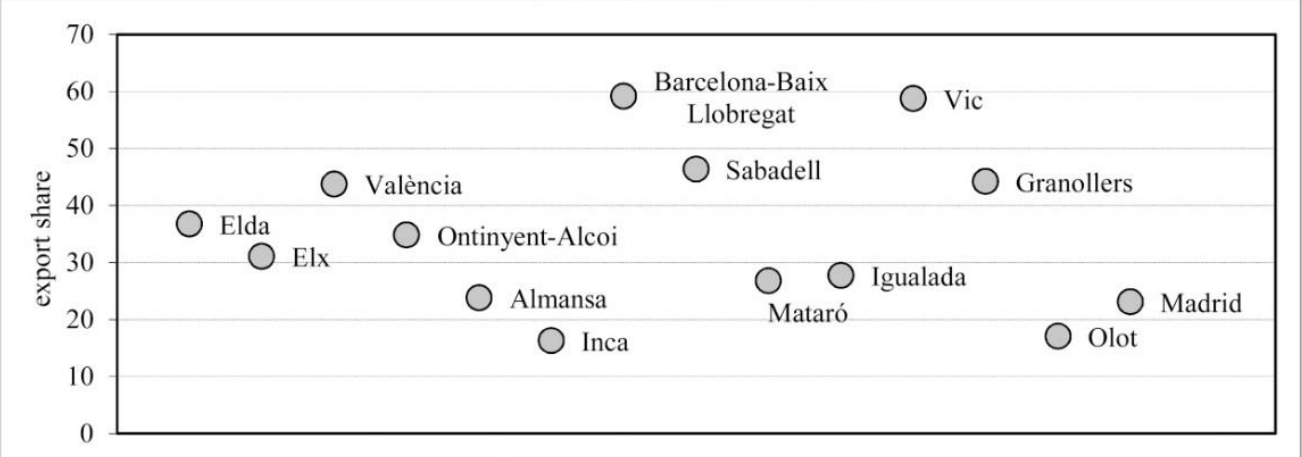

(b) Gini coefficient (GC)

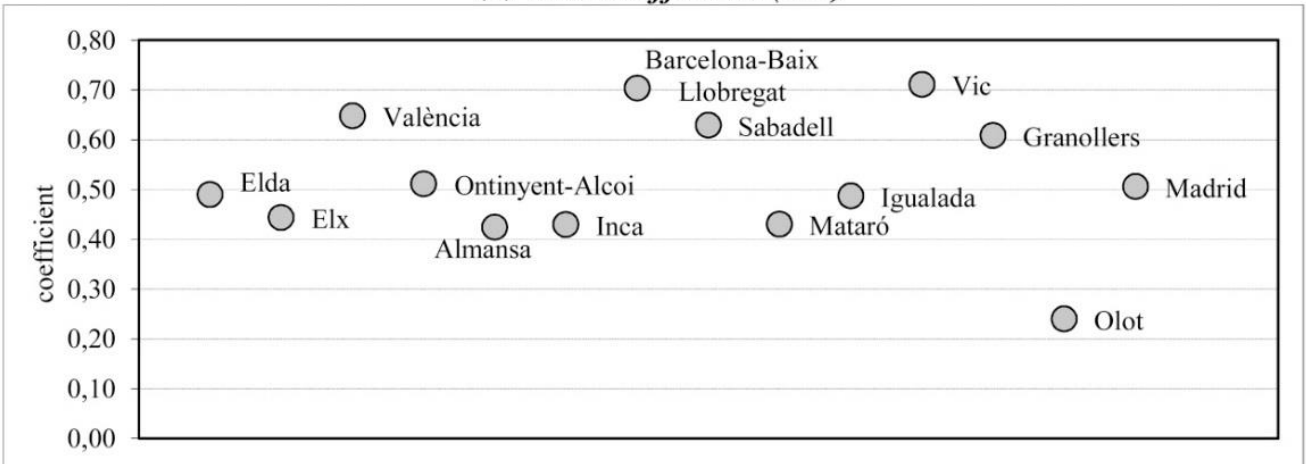

Notes and source: See table 2, appendix, text, and footnotes. 
Figure 3. The geographical origins of Spanish exports of textile, apparel, and footwear products, 2006/2007 (percentages).

(a) The top 10\% of exporting firms

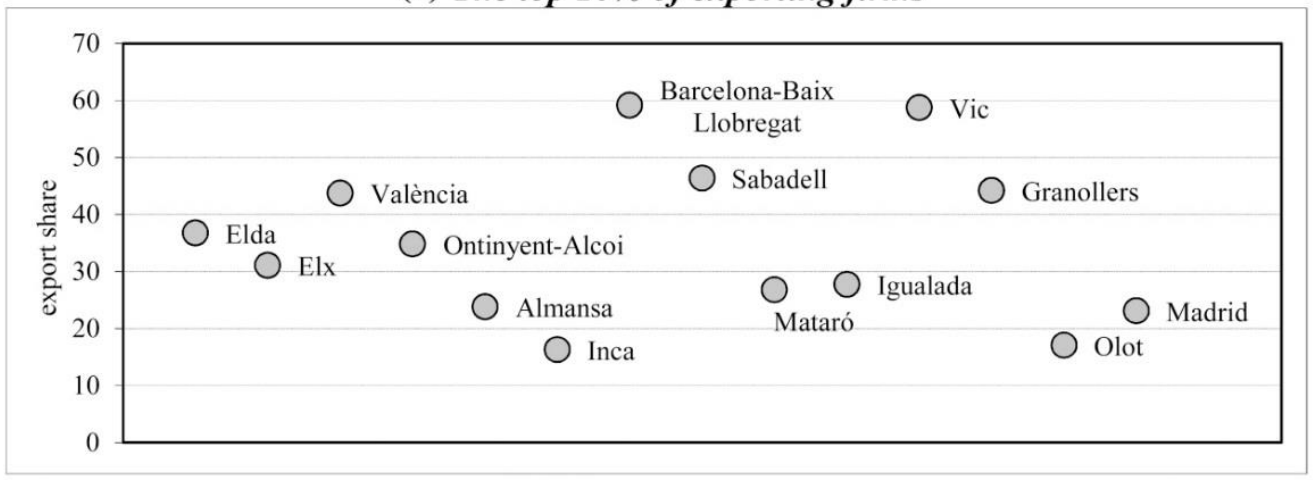

(b) Gini coefficient (GC)

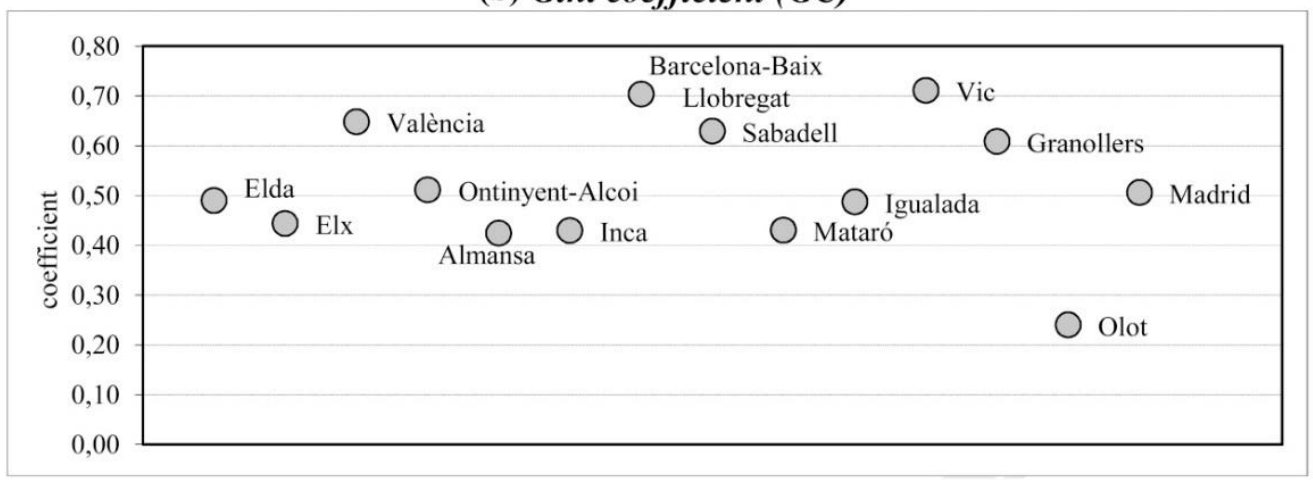

Notes and source: See text, and footnotes. 